\title{
Antiseptic and Aseptic Prophylaxis for Burns: Use of Silver Nitrate and of Isolators
}

\author{
J. S. CASON,* F.R.C.S. ; D. M. JACKSON,* M.D., F.R.C.S. ; E. J. L. LOWBURY,* M.A., D.M., F.C.PATH. \\ C. R. RICKETTS,* D.SC.
}

Brit. med.f., 1966, 2, 1288-1294

Local applications of neomycin, chlorhexidine, and polymyxin have been shown in controlled trials to protect burns against colonization by various pathogens, including Pseudomonas aeruginosa and Staphylococcus aureus (Cason and Lowbury, 1960 ; Lowbury, Miller, Cason, and Jackson, 1962b) ; earlier studies had shown the effectiveness of polymyxin cream in prophylaxis against Ps. aeruginosa (Jackson, Lowbury, and Topley, 1951). Though clinically useful, these prophylactic effects were limited, especially in the more extensive burns, and the emergence of neomycin-resistant Staph. aureus reduced their value (Lowbury, Babb, Brown, and Collins, 1964). The search for more effective methods was therefore continued.

Silver nitrate was formerly used on burns to accelerate the formation of dry slough (Bettman, 1936; Kalt, 1851). Recently Moyer, Brentano, Gravens, Margraf, and Monafo (1965) reported very successful results of treatment for extensive burns by application of compresses soaked in $0.5 \%$ silver nitrate solution; the method was claimed to prevent infection by various pathogens, including Ps. aeruginosa, which is widely recognized as a primary cause of death in extensively burned patients. In the same year Lindberg, Moncrief, Switzer, Order, and Mills (1965) reported a comparable control of wound sepsis by the local application of a cream containing $10 \%$ p-aminomethylbenzene sulphonamide (Sulfamylon).

Another approach in the control of infection has been the use of air-conditioning to prevent airborne infection (Bourdillon and Colebrook, 1946 ; Lowbury, 1954); further developments on these lines are the use of ventilated isolation rooms and of plastic isolators in which the patient is protected both against airborne contamination and against bacteria transmitted by contact (Levenson, Trexler, LaConte, and Pulaski, 1964 ; Haynes and Hench, 1966).

In this paper we describe controlled trials which give evidence of the value of antiseptic prophylaxis for burns (especially silver nitrate compresses). Some studies on aseptic methods, including a trial of ventilated isolation rooms and a preliminary trial of plastic isolators, are also reported.

\section{Trials of Antiseptic Prophylaxis \\ 1. Controlled Trial of Compresses and Creams}

\section{Methods}

Patients with burns of more than $15 \%$ of the body surface (more than $10 \%$ in children under 10 years of age) were allocated in rotation to the following treatment groups: (1) silver nitrate compresses, (2) silver nitrate cream, (3) chlorhexidine diacetate compresses, and (4) penicillin G cream (control series).

Solutions of silver nitrate $\left(0.5 \%^{1}\right.$ in distilled water) and of chlorhexidine diacetate $(0.1 \%$ in distilled water) were warmed

\footnotetext{
* From the M.R.C. Industrial Injuries and Burns Research Unit, Birm ingham Accident Hospital, Birmingham.

${ }^{1}$ Silver nitrate $(0.5 \%)$ is $0.03 \mathrm{~N}$; sodium chloride $(0.9 \%)$ is $0.15 \mathrm{~N}$ : serum chloride $(100 \mathrm{mEq} / 1$.) is $0.1 \mathrm{~N}$.
}

and applied to burns, as described by Moyer et al. (1965), on gauze compresses as soon as possible after admission of the patient and after shock was controlled. The gauze was retained in place with bandages and kept moist by three-hourly additions of the antiseptic solutions. The dressings were changed daily.

Silver nitrate $(0.5 \%)$ cream and penicillin G (1,000 units/g.) cream were made up in a lanette wax base (Colebrook, 1950), which was adopted after tests had shown that it was compatible with silver nitrate. The cream was applied to burns on gauze in an air-conditioned dressing-station, as described elsewhere (Jackson et al., 1951). Dressings were applied on the day of admission and usually changed every two or three days, or at shorter intervals when they became soaked with exudate.

Exposed burns (on face and neck) of patients in the groups receiving treatment with silver nitrate compresses and creams or chlorhexidine compresses were treated with applications of solutions of these agents two-hourly; exposed burns of patients in the control (penicillin cream) group received no local antibacterial application.

The local antibacterial applications were used continuously from the day of admission until the day of operation or (in partial-skin-thickness burns) until the burn was healed.

Serum levels of electrolytes were determined on the day after admission and then twice weekly.

All patients treated with silver nitrate had the following daily supplements of electrolytes by mouth, in dosage related to the body weight and area of burns: sodium chloride (10-30 g.), calcium lactate $(4-8 \mathrm{~g}$.), and potassium glutamate $(80-120 \mathrm{mEq})$. If more than $15 \mathrm{~g}$. of salt was given daily in the diet, $30-80 \mathrm{ml}$. of molar sodium lactate was also given by mouth to prevent acidosis (Moyer et al., 1965).

All patients were treated with oral cloxacillin $(250 \mathrm{mg}$. sixhourly for seven days).

\section{Bacteriological Study}

Swabs moistened with $10 \%$ broth-saline were taken daily from the burns treated with compresses or exposed, and at changes of dressings from those treated with cream; they were inoculated on culture media with a minimum of delay (usually within half an hour). Cultures on horse blood agar (with $4 \%$ agar), on improved cetrimide agar (Brown and Lowbury, 1965), and in cooked meat broth were set up and examined as described elsewhere (Lowbury, 1960 ; Lowbury, Lilly, and Wilkins, 1962a) ; for the identification of Gram-negative rods methods described by Cowan and Steel (1965) were used. Tests for carry-over of inhibitory amounts of antibacterial agents were made by inoculation of duplicate swabs, of inoculated culture media showing no growth, and of unused swabs and media (controls) with a dilute suspension of a strain of Ps. aeuroginosa. Swabs were allowed to stand for half an hour before inoculation on culture media.

Blood cultures were taken at the end of the shock stage and twice-weekly thereafter; also when the temperature rose to $103^{\circ} \mathrm{F} .\left(39.4^{\circ}\right.$ C. $)$ or above. 
Tests for inhibition of bacterial strains by silver nitrate in culture media were used to assess the sensitivity of strains of Ps. aeruginosa, Staph. aureus, Proteus spp., and miscellaneous Gram-negative bacilli (" coliform bacilli"). Tubes of nutrient broth and plates of nutrient agar containing doubling dilutions of silver nitrate were inoculated with 1 in 1,000 dilutions of suspensions of bacteria in distilled water, prepared from overnight broth cultures; cultures were examined for growth after overnight incubation at $37^{\circ} \mathrm{C}$.

Tests for bactericidal action of silver nitrate on strains of Ps. aeruginosa, Enterobacter aerogenes, and Klebsiella aerogenes were made as follows. Tubes containing serial dilutions of silver nitrate in distilled water $(1 \mathrm{ml}$.) were inoculated with $0.02-\mathrm{ml}$. amounts of washed suspensions containing approximately $6 \times 10^{5}$ organisms $/ \mathrm{ml}$. of distilled water. After these tubes had stood for five minutes at room temperature $0.02-\mathrm{ml}$. amounts were transferred from each tube to $10-\mathrm{ml}$. amounts of nutrient broth; these cultures were examined for growth after 42 hours' incubation.

\section{Clinical Study}

An analysis was made of the mortality, temperature and respiration rates, skin-grafting results, and times from injury to separation of slough of patients in the treatment and control groups.

\section{Bacteriological Results}

The proportion of burns from which various pathogens were isolated in the controlled trial is summarized in Table $I$. Because of the frequent isolation of Ps. aeruginosa from burns treated with chlorhexidine compresses and the complaints of pain after chlorhexidine applications only four patients were admitted to this group; ten patients were treated with silver nitrate cream, nine with silver nitrate compresses, and eight with penicillin cream ; no swabs were obtained from one patient in the last group.

The frequency of isolation of Ps. aeruginosa from burns was significantly lower in those treated with silver nitrate compresses (10.9\% on solid medium) than in the controls treated with penicillin cream $(51.2 \%)$. Burns dressed with silver nitrate cream were also less often infected with Ps. aeruginosa than the controls, though the effect of the cream was significantly less than that of silver nitrate compresses. The burns dressed with chlorhexidine compresses became colonized with Ps. aeruginosa as often as those in the control series. The incidence of Proteus spp. in the burns was affected by the different forms of local treatment in the same way as that of Ps. aeruginosa, though to a smaller degree. Coliform bacilli, which included many strains of Bacterium anitratum, E. aerogenes, E. cloacae, and Klebsiella spp., occurred in the burns of each treatment group with approximately the same frequency. Staph. aureus was present in about the same proportion of burns treated with silver nitrate compresses and with penicillin cream, but in a significantly smaller proportion of burns treated with chlorhexidine compresses than in those treated with silver nitrate compresses.

There was less evidence of prophylaxis by silver nitrate when applied as a solution to exposed burns. Ps. aeruginosa was isolated from 13/46 swabs (5/6 burns) from the face and neck in the group treated with silver nitrate compresses, and from $37 / 51$ swabs (7/10 burns) from these areas in the silver nitrate cream group ; $12 / 15$ swabs ( $3 / 3$ burns) from faces and necks in the penicillin group yielded Ps. aeruginosa.

When the assessment of bacteriology was analysed in terms of numbers of swabs yielding bacteria, silver nitrate compresses were seen to have an effect against Staph. aureus, though not as great as the effect against Ps. aeruginosa and Proteus spp.; they had no effect against coliform bacilli (see Table II).

TABLe II.-Controlled Trial of Antiseptic Prophylaxis for Extensio Burns : Bacterial Colonization (2)

\begin{tabular}{|c|c|c|c|c|}
\hline \multirow{2}{*}{ Bacteria } & \multicolumn{4}{|c|}{$\begin{array}{l}\text { Swabs from which Bacteria were Isolated durins Treatment } \\
\text { with: }\end{array}$} \\
\hline & $\begin{array}{l}\text { Silver Nitrate } \\
\text { Compresses }\end{array}$ & $\begin{array}{l}\text { Silver Nitrate } \\
\text { Cream }\end{array}$ & $\begin{array}{l}\text { Penicillin } \\
\text { Cream }\end{array}$ & $\begin{array}{l}\text { Chlorhexidine } \\
\text { Compresses }\end{array}$ \\
\hline $\begin{array}{l}\text { Ps. aeruginosa } \\
\text { Proteus spp. } \\
\text { Coliform bacilili } \\
\text { Staph. aureus }\end{array}$ & $\begin{array}{c}16(3.1 \%) \\
27(5.3 \%) \\
273(54 \%) \\
38(7.5 \%)\end{array}$ & $\begin{array}{r}79(34 \%) \\
56(24 \%) \\
100(42 \%) \\
96(41 \%)\end{array}$ & $\begin{array}{l}95(70 \%) \\
60(44 \%) \\
55(40.5 \%) \\
31(23 \%)\end{array}$ & $\begin{array}{l}65(55 \%) \\
23(20 \%) \\
35(30 \%) \\
1(0.8 \%) \\
\end{array}$ \\
\hline Total swabs & 509 & 235 & 136 & 117 \\
\hline
\end{tabular}

Streptococcus pyogenes was not isolated from any burns during the trial.

A much larger proportion of swabs from burns treated with silver nitrate compresses than of those from other groups yielded no bacterial growth (Table III).

TABLE III.-Controlled Trial of Local Prophylaxis for Extensive Burm : No Growth or Very Scanty Growth of Bactiria

\begin{tabular}{|c|c|c|c|c|}
\hline & \multicolumn{4}{|c|}{$\begin{array}{l}\text { Burn Swabs from which No Bacteria or Very Scanty } \\
\text { Bacteria were Obtained on Treatment with: }\end{array}$} \\
\hline & $\begin{array}{c}\text { Silver Nitrate } \\
\text { Compresses }\end{array}$ & $\begin{array}{c}\text { Silver Nitrate } \\
\text { Cream }\end{array}$ & $\begin{array}{c}\text { Penicillin } \\
\text { Cream }\end{array}$ & $\begin{array}{l}\text { Chlorhexidine } \\
\text { Compresses }\end{array}$ \\
\hline No growth (n.g.) . & $113(22 \cdot 2 \%)$ & $17(7 \cdot 2 \%)$ & $4(2 \cdot 9 \%)$ & $7(6.0 \%)$ \\
\hline $\begin{array}{l}\text { Very scanty growth } \\
\begin{array}{c}\text { (v.s.g.) } \\
\text { n.g. + v.s.g. }\end{array}\end{array}$ & $\begin{array}{r}61(12 \cdot 0 \%) \\
174(34 \cdot 2 \%) \\
\end{array}$ & $\begin{aligned} 9 & (3 \cdot 8 \%) \\
26 & (11 \cdot 1 \%)\end{aligned}$ & $\begin{array}{l}1(0.7 \%) \\
5(3.6 \%)\end{array}$ & $\begin{aligned} 3(2.5 \%) \\
10(8.5 \%)\end{aligned}$ \\
\hline Total swabs & 509 & 235 & 136 & 117 \\
\hline
\end{tabular}

Although some of the strains of coliform bacilli were " resistant" to silver nitrate (see Table IV), many sensitive strains were also found on burns treated with silver nitrate compresses. These organisms, unlike Ps. aeruginosa, were of types commonly found in faeces, and were probably acquireo in burns from the patients' own flora before silver nitrate treatment began. The application of silver nitrate compresses (see below) has not been found to remove organisms already colonizing a burn.

TABLE I.-Controlled Trial of Local Prophylaxis for Extensive Burns : Bacterial Colonization (1)

\begin{tabular}{|c|c|c|c|c|c|c|c|c|c|c|c|c|c|c|c|c|c|c|c|c|c|}
\hline \multirow{3}{*}{ Bacteria } & & \multicolumn{20}{|c|}{ Burns from which Bacteria were Isolated during Period of Prophylactic Treatment with: } \\
\hline & & \multicolumn{5}{|c|}{ Silver Nitrate Compresses } & \multicolumn{5}{|c|}{ Silver Nitrate Cream } & \multicolumn{5}{|c|}{ Penicillin Cream } & \multicolumn{5}{|c|}{ Chlorhexidine Compresses } \\
\hline & & + & \pm & 0 & $\%+$ & $\begin{array}{c}\%+ \\
\text { and } \\
\pm\end{array}$ & + & \pm & 0 & $\%+$ & $\begin{array}{c}\%+ \\
\text { and } \\
\pm\end{array}$ & + & \pm & 0 & $\%+$ & $\begin{array}{c}\%+ \\
\text { and } \\
\pm\end{array}$ & + & \pm & $\mathbf{0}$ & $\%+$ & $\begin{array}{c}\%+ \\
\text { and } \\
\pm\end{array}$ \\
\hline Ps. aeruginosa & .. & 7 & 5 & 52 & $\begin{array}{l}\text { a,c } \\
10 \cdot 9\end{array}$ & $\underset{18 \cdot 8}{d}$ & 15 & 16 & 29 & $\begin{array}{l}b, c \\
25 \cdot 0\end{array}$ & $\underset{51 \cdot 7}{d}$ & 21 & 12 & 8 & $\begin{array}{l}a, b \\
51 \cdot 2\end{array}$ & $80 \cdot 5$ & 15 & 0 & 10 & $60 \cdot 0$ & 60.0 \\
\hline $\begin{array}{l}\text { Proteus spp. } \\
\text { Coliform bacili }\end{array}$ & $\because$ & $\begin{array}{l}12 \\
42\end{array}$ & $\begin{array}{l}6 \\
6\end{array}$ & $\begin{array}{l}46 \\
16\end{array}$ & $\begin{array}{l}18 \cdot 8 \\
65 \cdot 6\end{array}$ & $\begin{array}{l}28 \cdot 1 \\
75 \cdot 0\end{array}$ & $\begin{array}{l}25 \\
40\end{array}$ & $\begin{array}{l}1 \\
0\end{array}$ & $\begin{array}{l}34 \\
20\end{array}$ & $\begin{array}{l}41.7 \\
66.6\end{array}$ & $\begin{array}{l}43 \cdot 3 \\
66 \cdot 6\end{array}$ & $\begin{array}{l}29 \\
23\end{array}$ & $\begin{array}{l}3 \\
2\end{array}$ & $\begin{array}{r}9 \\
16\end{array}$ & $\begin{array}{l}70 \cdot 8 \\
56 \cdot 1\end{array}$ & $\begin{array}{l}78 \cdot 0 \\
60 \cdot 9\end{array}$ & $\begin{array}{r}9 \\
18\end{array}$ & $\begin{array}{l}3 \\
1\end{array}$ & $\begin{array}{r}13 \\
6\end{array}$ & $\begin{array}{l}36 \cdot 0 \\
72 \cdot 0\end{array}$ & $\begin{array}{l}480 \\
7600\end{array}$ \\
\hline Staph. aurew & . & 19 & 2 & 43 & $29 \cdot 7$ & $32 \cdot 8$ & 33 & 0 & 27 & $\begin{array}{c}\mathrm{h} \\
55 \cdot 0\end{array}$ & $55 \cdot 0$ & 14 & 1 & 26 & $\underset{34 \cdot 1}{h}$ & $36 \cdot 6$ & 1 & 0 & 24 & 0 & $4 \cdot 0$ \\
\hline
\end{tabular}

Significance tests: The letters indicate pairs of treatment groups between which scanty growth (in liquid medium only). 


\section{Blood Cultures}

Bacterial growth from two bottles was obtained in $3 / 24$ cultures from patients in the series treated with silver nitrate compresses ; none of these yielded Ps. aeruginosa. There were $9 / 33$ positive cultures (two bottles) in the series treated with silver nitrate cream, and $8 / 27$ positives in the series treated with penicillin cream and in the series treated with chlorhexidine compresses. Ps. aeruginosa was found in one culture from each of these three series.

\section{Sensitivity of Burn Flora to Silver Nitrate}

Because silver is precipitated by chloride in culture media, the results of tube or plate dilution tests cannot be adequately expressed as the minimal inhibitory concentration of the salt. But though most of the silver is precipitated even the small concentration of silver ions in equilibrium with precipitated silver chloride is bactericidal. Most strains of Ps. aeruginosa and other bacteria from burns do in fact show a sharp endpoint in tube or plate dilution tests, and it is possible to distinguish differences in sensitivity of strains by this method.

Table IV shows the results of testing strains of burn flora by plate dilution tests (plates were used for most of the tests because the results of replicate tests were more consistent in the plate than in the tube dilution method). All of the strains of Ps. aeruginosa tested were inhibited (most of them completely) on plates of agar containing initial concentrations of silver nitrate much below $0.5 \%$. Most strains, including those isolated from burns treated with silver nitrate compresses in this unit, showed end-points within a range of initial dilutions between 0.001 and $0.002 \%$, but a few strains were slightly more resistant. Two strains showing greater resistance (not included in Table IV) were from burns of patients treated with silver nitrate at St. Louis, Missouri ; they gave very scanty growth on plates initially containing from 0.0078 to $0.5 \%$ silver nitrate, and grew well in plates containing $0.0039 \%$ silver nitrate.

\begin{tabular}{|c|c|c|c|c|c|c|c|}
\hline \multirow{2}{*}{ Bacteria } & \multicolumn{7}{|c|}{$\begin{array}{l}\text { Minimal Inhibitory Concentrationt of Silver Nitrate (\%) for } \\
\text { Strains of Bacteria }\end{array}$} \\
\hline & 0.00049 & 0.001 & 0.002 & 0.0039 & 0.0078 & $>0.5$ & Total \\
\hline $\begin{array}{l}\text { Ps. aeruginosa } \\
\text { Staph. aureus } \\
\text { Colliform bacilli } \\
\text { Proteus } \quad \text {. }\end{array}$ & $\begin{array}{l}0 \\
0 \\
0 \\
0\end{array}$ & $\begin{array}{r}35 \\
0 \\
16 \\
22\end{array}$ & $\begin{array}{l}53 \\
32 \\
12 \\
21\end{array}$ & $\begin{array}{r}4 \\
20 \\
1 \\
3\end{array}$ & $\begin{array}{l}0 \\
0 \\
0 \\
0\end{array}$ & $\begin{array}{l}0 \\
0 \\
4^{*} \\
0\end{array}$ & $\begin{array}{l}92 \\
52 \\
33 \\
46\end{array}$ \\
\hline
\end{tabular}

Moderate growth on plates containing 0.0078 to $0.5 \%$ silver nitrat

t M.I.C. refers to the concentration of silver nitrate initiaily added to the moditin

Strains of $K$. aerogenes from a burn treated with silver nitrate compresses grew moderately well on plates containing $0.5 \%$ silver nitrate, as did some other Gram-negative bacilli (E. aerogenes and $E$. cloacae).

Strains of Staph. aureus were inhibited on plates containing initial concentrations of 0.002 to $0.0039 \%$ of silver nitrate.

The highest dilution of silver nitrate in distilled water which killed added bacterial suspensions in five minutes was $0.13 \mu \mathrm{g}$./ ml. $(0.000013 \%)$ for Ps. aeruginosa from burns in this hospital, $20 \mu \mathrm{g} . / \mathrm{ml}$. for a strain from a burn at St. Louis, Missouri, and $20 \mu \mathrm{g} . / \mathrm{ml}$. for a strain of $K$. aerogenes isolated from a burn treated with silver nitrate compresses; the strains which were more resistant to silver nitrate by this test were also more resistant in the plate dilution test.

\section{Clinical Results}

Because compresses were kept wet with silver nitrate solution for two to three weeks at a time, this treatment was uncomfortable ; some patients receiving it appeared to be apathetic or miserable. After changing to more orthodox dressings the patients' morale improved and they said they were more comfortable.

Gauze compresses were changed daily, and they were often found to adhere to burns of partial skin-thickness; bleeding often occurred on removal of the compresses, even when they were soaked with silver nitrate solution. In one case the loss of blood after several dressings was so great that a blood transfusion had to be given.

The staining of the skin, bedclothes, dressings, and walls by the silver compound looked dirty, but this was partially camouflaged by the use of dark-blue sheets.

Slough Separation Time.-The mean time from the day of injury to the day when full-skin-thickness burns were ready for operation was nearly four days longer in burns treated with silver nitrate compresses (21.1 days) than in those treated with penicillin cream (17.3 days). A similar difference between burns treated with neomycin-chlorhexidine tulle gras and controls treated with penicillin cream was reported earlier and thought to be due to the exclusion of proteinase-producing bacteria by the more active antibacterial application (Lowbury et al., 1962b). The mean slough separation time of burns treated with silver nitrate cream was 18.2 days.

Skin-grafting Results.-In spite of the longer period of slough separation (and in contrast to earlier findings with neomycin-chlorhexidine tulle gras), burns treated with silver nitrate compresses showed a higher proportion of successful grafts $(13 / 13$ with $80 \%$ or more " take ") than those treated by the other methods (silver nitrate cream $9 / 13$, penicillin cream $8 / 15$, and chlorhexidine compresses $6 / 12$ grafts with $80 \%$ or more " take").

\section{Temperature and Respiration Rate}

The daily mean morning and evening temperatures of patients for the first week in all four groups of the trial are shown in Fig. 1. It shows a rising trend in all treatment groups except the group treated with silver nitrate compresses. The cooling. effect of these compresses by evaporation could not be regarded as the only cause for the lower temperature, since a similar effect was not seen in patients cooled with chlorhexidine compresses.

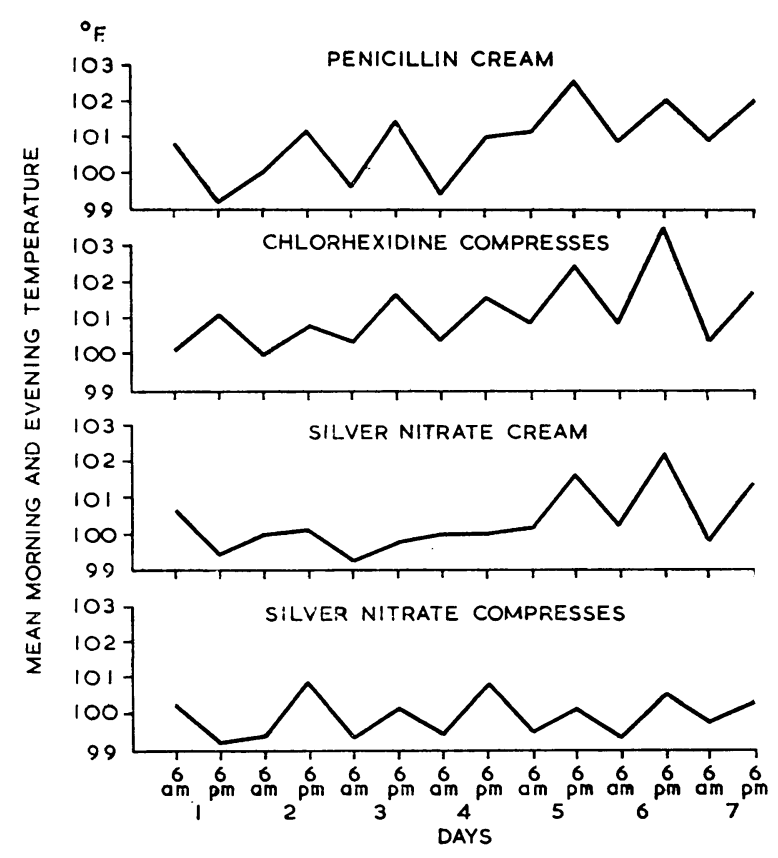

FIG. 1.-Mean morning and evening temperatures during the first week of patients in the prophylactic trial of silver nitrate compresses and other applications to burns. The patients treated with silver nitrate compresses had lower mean temperatures than those in the other groups. 
The mean temperature and respiration rates for the first three weeks of patients in the main groups of the trial were assessed. Those treated with silver nitrate compresses had lower mean temperatures than the controls treated with penicillin cream (mean difference of mean temperatures $=0.77, \sigma_{\mathrm{m}}=0.1, \mathrm{t}=7.7$, $\mathrm{P}<0.01)$; the mean difference between mean temperatures of patients in the groups treated with silver nitrate cream and penicillin cream (0.47) was also significant $\left(\sigma_{\mathrm{m}}=0.095, \mathrm{t}=5.4\right.$, $P<0.02)$, as was the mean difference $(0.3)$ in the comparison between patients treated with silver nitrate cream and silver nitrate compresses $\left(\sigma_{m}=0.07, t=4.3, P<0.05\right)$. The mean respiration rate was higher in patients treated with penicillin cream than in those treated with silver nitrate compresses (mean difference of means $=2.7, \sigma_{m}=0.137 ; t=7.3, P<0.01$ ); the mean respiration rate of the group treated with silver nitrate cream was lower than that of the group treated with silver nitrate compresses, but the difference was not significant (mean difference of means $=2.9, \sigma_{\mathrm{m}}=1.05, \mathrm{t}=2.9, \mathrm{P}>0.05$ ).

\section{Mortality}

The observed mortality of the small series of patients treated with silver nitrate compresses was lower (2) than the expected mortality of 2.5 , estimated on the basis of patients' age and area of burns (Bull and Fisher, 1954). When the pilot study was grouped with the controlled trial, 16 patients were treated with silver nitrate compresses. Two of these patients died, and the expected mortality of the series was 2.8. One of the patients in this group who survived was a girl of 10 years with burns (mostly of full-skin-thickness) extending over $73 \%$ of the body surface ; the burn did not acquire $P$ s. aeruginosa during treatment, but a heavy growth of $E$. aerogenes and Bact. anitratum was grown from most of the burns. Five of the patients in the silver nitrate cream series and two of those in the penicillin cream series died; the expected mortalities were respectively 3.7 and 2.0.

\section{Serum Electrolyte Levels}

The mean concentrations of sodium (135.1 mEq/1.), potassium (4.5 mEq/1.), and chloride $(99.3 \mathrm{mEq} / 1$.) and the alkali reserve $(24.25 \mathrm{mEq} / 1$.) in the serum of patients treated with silver nitrate compresses were within normal limits.

\section{Comparability of Patients in Trial}

The mean estimated area of burns and age of patients in the treatment and control groups were as follows: silver nitrate compresses, $27.0 \%, 12.9$ vears ; silver nitrate cream, $31.1 \%$, 23.6 years ; penicillin cream, $30.1 \%, 16.8$ years ; chlorhexidine compresses, $29.0 \%, 3.25$ years.

\section{Controlled Trial of Silver Nitrate Cream for Smaller Burns}

The use of silver nitrate compresses is time-consuming for the staff and uncomfortable for the patients. Smaller burns, in which the potentially life-saving role of compresses is not required, should nevertheless be given local treatment which reduces the hazard of infection. Silver nitrate cream, though less effective than silver nitrate compresses, was shown to have some value in protecting extensive burns against Ps. aeruginosa and Proteus spp.

To determine the prophylactic value of silver nitrate cream as a routine prophylactic application in a burns unit, a controlled trial was made on patients admitted with fresh burns of up to $20 \%$ of the body surface. Alternate cases were allocated for local treatment with silver nitrate cream $(0.5 \%$ in a lanette wax emulsion base) and to a control series in which penicillin cream (1,000 units/g.) was applied. The conduct of the trial and the bacteriological study were carried out in the manner described previously (see Lowbury et al., 1962b, and above).

Table V summarizes the bacteriological results. The burns treated with silver nitrate cream showed a significantly lower incidence of infection with Ps. aeruginosa and Proteus spp. than those treated with penicillin cream ; other Gram-negative bacilli were also less frequently isolated from burns treated with silver nitrate cream. Staph. aureus, on the other hand, was almost significantly more common in burns dressed with silve:

TABLE V.-Controlled Trial of Silver Nitrate Cream

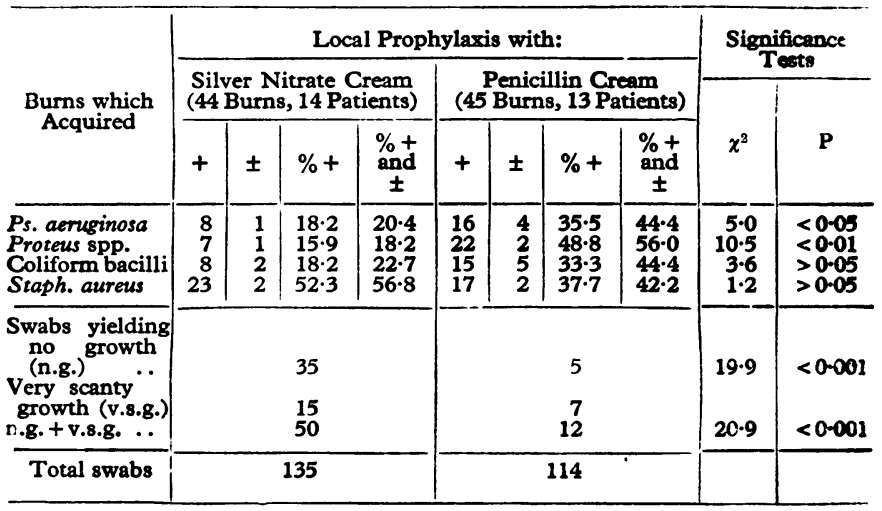

nitrate cream than in those of the control series. Factors tha: may account for this effect are (1) suppression of Staph. aureus because of profuse growth of Gram-negative bacilli in burne treated with penicillin cream, and (2) interference with the action of systemic cloxacillin against Staph. aureus on burns. Silver nitrate was found to be compatible with cloxacillin, bu: the drier surface under silver nitrate might have interfered witl the diffusion of the antibiotic to the organisms.

\section{Effect of Silver Nitrate Compresses on Burns Infected with \\ Ps. aeruginosa}

Pilot observations showed no removal or reduction of $P_{\text {s. }}$. acruginosa from burns which were already colonized with the organism when treatment was started.

\section{Toxicity of Silver Nitrate}

Use of silver nitrate for prophylaxis against $P$ s. aeruginoso raises the question of whether there is a risk of argyria, the permanent discoloration of the skin remote from the site of application of the silver and usually occurring in areas exposed to light ; we have seen no clinical evidence of this.

It seemed possible, however, that silver might be transported in the blood stream and deposited elsewhere. Table VI shows the silver content of tissues from patients with burns. The skin examined was from a skin-graft-donor site carefully pro-

\begin{tabular}{|c|c|c|c|c|c|}
\hline $\begin{array}{c}\text { Age } \\
\text { of } \\
\text { Patients }\end{array}$ & $\underset{(\%)}{\text { E.A.B. }}$ & $\begin{array}{c}\text { Silver Nitrate } \\
\text { Treatment } \\
\text { (Days) }\end{array}$ & $\begin{array}{c}\text { Time } \\
\text { of } \\
\text { Sample }\end{array}$ & $\begin{array}{l}\text { Tissue } \\
\text { of } \\
\text { Fluid }\end{array}$ & $\underset{\text { (mg./kg.) }}{\text { Silver }}$ \\
\hline 6 & 19 & 7 & Day 8 & $\begin{array}{l}\text { Skin } \\
\text { Serum }\end{array}$ & $\begin{array}{r}<12.2 \\
1.0\end{array}$ \\
\hline 7 & 17 & 7 & " 7 & $\begin{array}{l}\text { Urine } \\
\text { Serum }\end{array}$ & $\begin{array}{l}<0.1 \\
<0.5\end{array}$ \\
\hline 2 & 80 & 5 & P.M. & $\begin{array}{l}\text { Kidney } \\
\text { Spleen } \\
\text { Brain }\end{array}$ & $\begin{array}{r}38 \\
13.5 \\
1.3\end{array}$ \\
\hline
\end{tabular}

Note th $\mathrm{t} \mathrm{mg} . / \mathrm{kg}$. is parts per million. E.A.B. $=$ Estimated area of burn. 
tected from contamination before starting treatment with silver nitrate; $163.6 \mathrm{mg}$. of skin was available for analysis, and in this weight the amount of silver present was less than $2 \mu \mathrm{g}$., the limit of measurement.

The figures do provide some evidence for transport of silver in the blood stream, and it is relevant to consider mixtures of silver nitrate with serum in vitro. When $1 \mathrm{ml}$. of $0.1 \mathrm{~N} \mathrm{AgNO}_{3}$ $(1.7 \%)$ containing radioactive silver $\left({ }^{11} \mathrm{Ag}\right)$ was mixed with 2 $\mathrm{ml}$. of serum a precipitate formed and was separated by centrifuging. The supernatant solution was analysed on a column of Sephadex G-200 in saline. The distribution of silver as shown by radioactivity and the distribution of protein as shown by uitraviolet absorption were recorded. Insoluble colloidal silver compounds were present in the void volume from the column and rather small amounts of silver were found associated with protein but not coinciding with either of the protein peaks. A similar experiment in which the mixture was separated by electrophoresis showed silver moving with the mobility of alphaor beta-globulins but not coinciding with an electrophoretic fraction. Probably the silver found in the circulation a day after removing the silver nitrate dressings was in the form tound to move with the proteins in the experiments described.

Analysis of tissues taken at post-mortem examination showed considerable amounts of silver in liver, kidney, and spleen. As these tissues are richest in reticuloendothelial cells, which take up insoluble material from the blood stream, it seems likely that colloidal silver compounds found in the void volume of the Sephadex column are taken up by these cells.

An excellent account of argyria is given by Hill and Pillsbury (1939), and it is interesting to compare the silver content of tissues from patients with argyria quoted in this book with those from a patient with burns shown in Table VI. The most reliable data seem to be those of Geitler, Rhoades, and Weiss (1927), who found $700 \mathrm{mg} . / \mathrm{kg}$. in liver, $2,400 \mathrm{mg} . / \mathrm{kg}$. in kidney, and $110 \mathrm{mg} . / \mathrm{kg}$. in brain; earlier figures are lower and probably less reliable.

It will be seen that silver content of the tissues from burn patients are lower by a factor of 17 times for liver, 63 times for kidney, and 85 times for brain than the corresponding tissues for argyria patients. The available data show that less silver sccumulated in the patients with burns than in the cases of argyria reported in the literature. Hill and Pillsbury (1939) suggest that the danger of argyria is very slight if the total amount of silver nitrate ingested by mouth is below $6 \mathrm{~g}$. In 192 cases of generalized therapeutic argyria listed only one resulted from treatment of a burn with silver nitrate.

\section{Pilot Studies}

In addition to the controlled trials reported above several pilot studies on local antibacterial prophylaxis were made. Sulfamylon was applied, with dressings, to burns of two patients in a cream containing $10 \%$ of the agent. Both patients complained of severe pain, so the treatment was abandoned before its prophylactic value could be assessed. In a pilot controlled trial a gel containing $2.5 \%$ polynoxylin and a tulle containing framycetin, polymyxin, and bacitracin showed promise of useful prophylaxis, but polynoxylin caused pain, irritation, and diszomfort, and also adherence of dressings. Replacement of the gel base by a cream resulted in less adherence but no diminution in the pain caused by dressings. An attempt to use the more soluble related compound noxythiolin in compresses was abandoned because formaldehyde vapour was produced on warming the solution. Compresses of a hypochlorite solution (Milton $1 / 80$ ) applied on a burn of the right arm did not prevent heavy persistent colonization from the sixth day with Ps. aeruginosa. Similar burns on the left arm of the same patient treated with silver nitrate compresses remained free from $P$ s. aeruginosa for over four weeks.

\section{Studies on Isolation Methods}

\section{Isolation in Cubicles}

\section{(a) Conversion of an Open Ward}

In 1961 an open ward of the burns unit was converted into one with eight two-bedded rooms of $1,400 \mathrm{cu}$. ft. (39.6 cu. m.) and two single-bedded rooms of $840 \mathrm{cu}$. ft. $(23.8 \mathrm{cu}$. m.). When the ward was reopened the nursing techniques used for patients were similar to those which had been in use before the conversion.

In six-month periods (November to April) of the years 1958-9 and 1959-60 Staph. aureus was acquired by $86 / 107$ patients and $87 / 119$ patients respectively; in the corresponding periods of 1961-2 and 1962-3 (after the conversion of the ward) the staphylococcal infection rates were $76 / 107$ and $80 / 117$ respectively. Ps. aeruginosa was isolated from 31 and 35 patients in the two phases of the earlier period, and from 31 and 36 patients in the two phases of the later period.

\section{(b) Controlled Trial of Air-conditioned Cubicles}

Four of the two-bedded and one of the single-bedded rooms in the ward described above were equipped from December 1962 with portable air-conditioning units (Westair Model 300 Climatiser), which delivered air (four-fifths recirculated and one-fifth from the exterior) with an output of approximately $180 \mathrm{cu}$. ft. $(5.1 \mathrm{cu} . \mathrm{m})$ per minute. The recirculated air passed through glass-fibre filters which were estimated to remove 95$97 \%$ of particles of mean diameter more than $5 \mu$. Filters were changed weekly. Doors of cubicles were kept shut.

A comparison was made of the bacteriology of burns and environment in the air-conditioned and window-ventilated rooms. Thirty-three patients with fresh burns were admitted to each group of cubicles. Settle plates of phenolphthalein diphosphate agar (Barber and Kuper, 1951) were exposed every day for five hours in all cubicles. Burn flora were examined as described above.

The mean counts of total organisms and of presumptive Staph. aureus on settle plates per hour were lower in the airconditioned rooms $(55.2 \pm 2.3$ and $3.3 \pm 0.3$ respectively) than in the window-ventilated rooms $(82.7 \pm 2.9$ and $6.6 \pm 0.7$ respectively). There was, however, as high an incidence of acquired Staph. aureus (24/32), Str. pyogenes (5/32), and Ps. aeruginosa (14/33) on burns in patients treated in the airconditioned rooms as in those treated in rooms with window ventilation (20/26, $6 / 33$, and $10 / 33$ respectively); the figures refer to patients whose burns were free from the organisms on admission. Further studies are needed to establish the possible value of higher rates of ventilation.

\section{Study on the Use of an Isolator for Burned Patients}

Several designs of isolators were tried. The model chosen for further study was a large bag made of transparent flexible plastic sheeting (polyvinyl chloride) kindly produced for us by Vickers Research Ltd.; it was inflated with ward air (20 to 30 cu. ft. $/ \mathrm{min}$. ; 0.57 to $0.85 \mathrm{cu} . \mathrm{m} . / \mathrm{min}$.) warmed and pumped through a Mackley Pureair glass-fibre filter for removal of submicron particles. The isolator (Fig. 2) was suspended from a framework attached to the bed. It was provided with five glove ports on each side for the handling of patients ; in the earlier models these were open-ended sleeves, but the later models had gloves attached to the sleeves.

The isolator was opened to admit a patient by a longitudinal zip-fastener on the midline of the upper segment. There was a large pouch (air lock) on each side, with inner and outer zip- 
fasteners, for the transfer of materials in and out of the isolator ; one of these was used for clean materials (food, clean dressings, bedding, etc.), while the other was used for bedpans, urinals, and the removal of used dressings, bed-covers, and other "dirty" objects.

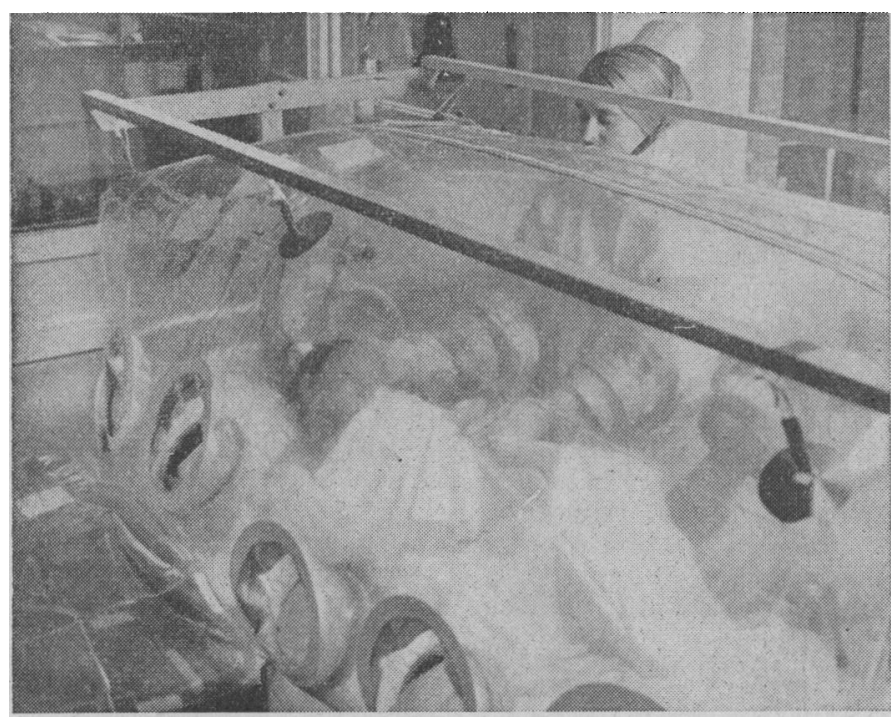

FIG. 2.-A plastic isolator for a burned child; ventilation through filters and the use of glove ports and service pouches on both sides make it possible to protect the patient against contamination by contact and from the air.

Our study involves assessments of the design and use of tsolators, and of their value in excluding bacteria from burned patients. The following notes record preliminary findings.

\section{(a) Airborne Bacteria in the Isolator}

A series of tests were made with settle plates and with a slit sampler on the air inside and outside the unoccupied ventilated isolator in a room where nine persons had been taking vigorous exercise for 15 minutes. The mean viable counts in three experiments were $60 / \mathrm{cu}$. ft. $(2,120 / \mathrm{cu}$. m.) outside and $0.9 / \mathrm{cu}$. ft. $(32 / \mathrm{cu} . \mathrm{m}$.) inside the isolator; mean settle plate counts per plate were 73 colonies (1.5 Staph. aureus) outside and 0.17 colonies (no Staph. aureus) inside the isolator.

In two studies with burned patients in the isolators the viable counts on slit sampler plates were in the range $1-4 / \mathrm{cu}$. $\mathrm{ft}$. $(35-140 / \mathrm{cu}$. m.) inside and $12-17 / \mathrm{cu}$. ft. (424-600/cu. m.) outside the isolators.

\section{(b) Bacteriology of Patients in Isolators}

In a pilot study three patients were treated in isolators for periods between 13 and 17 days. One patient was a child of two years with $50 \%$ of the body surface burned-(45\% full-skinthickness); during the 17 days while she was in the isolator Ps. aeruginosa did not appear on any burn. Of 22 other patients with burns of more than $30 \%$ who were in the ward during 1964 and 1965 and survived for more than four days all acquired Ps. aeruginosa between the second and eleventh days, and all but one had acquired the organism by the eighth day.

Of the two other patients in isolators one (14\% burn) acquired Ps. aeruginosa on the tenth day and the other $(13 \%)$ acquired the organism on the ninth day (sparse and transient contamination).

A controlled trial on the use of isolators is in progress and will be reported later.

\section{Discussion}

Silver nitrate applied in compresses of $0.5 \%$ solution as described by Moyer et al. (1965) was effective in keeping burns free from Ps. aeruginosa and, in some cases, from any detectable bacteria for periods as long as two to three weeks. The treatment also gave good prophylaxis against Proteus spp. and a smaller prophylactic effect against Staph. aureus, but there was no evidence that it had any prophylactic action against miscellaneous coliform bacilli. Many of these coliforms were sensitive to silver nitrate, but persisted in burns treated with silver nitrate compresses-perhaps because they, unlike Ps. aeruginosa, were acquired from the patients' intestinal flora before silver nitrate treatment began. Silver nitrate applications are apparently not effective in removing organisms already present on a burn, but certain Gram-negative rods (notably strains of $E$. aerogenes, $K$. aerogenes, and $E$. cloacae) were exceptionally resistant and could grow in culture medium to which silver nitrate was added to give an initial concentration of $0.5 \%$ of the salt. All strains of Ps. aeruginosa, Proteus spp., and Staph. aureus isolated here failed to grow in media which had received this addition of silver nitrate. Compresses of chlorhexidine, and, in a more limited study, of hypochlorite (Milton 1 in 80), did not show any prophylactic effects against Ps. aeruginosa, but chlorhexidine compresses appeared to be more active than silver nitrate against Staph. aureus.

The bacteriological effects of silver nitrate compresses were matched by good clinical results, including significantly lower mean temperature and respiration rates than those of the controls, and the mortality of the patients was also lower than that expected on the basis of their age and the area of burn, though the numbers were too small for significance. Though the mean slough separation time was longer in the burns treated with silver nitrate compresses than in those of the control series, the skin-grafting results were better in the former. Prolonged slough separation times had previously been found also in burns treated with neomycin-chlorhexidine-tulle gras, but in that series skin-grafting results had been poorer than in burns of the control series ; this prolonged slough separation was thought to be due to the suppression of proteinase-producing bacteria by the agents applied to the burns associated with dryness of the burn (Lowbury et al., 1962a).

Evidence from preliminary studies suggests that patients treated in ventilated plastic isolators receive useful protection against hospital flora-for example, Ps. aeruginosa, which has usually appeared in patients with more than $10 \%$ of the body surface burned (Lowbury and Fox, 1954), did not appear in a child with $50 \%$ of the surface burned during the 17 days that she spent in the isolator. There was evidence, too, that acquisition of Staph. aureus was delayed in patients treated in an isolator.

Other methods of prophylaxis were less effective than silver nitrate compresses. A cream containing $0.5 \%$ silver nitrate reduced the frequency of acquisition of Ps. aeruginosa by approximately $50 \%$, an effect somewhat smaller than that formerly obtained with polymyxin cream (Jackson et al., 1951; Cason and Lowbury, 1960). Patients so treated did, however, show evidence of clinical advantage (lower temperature and respiration rates than in the control series). Cubicles ventilated by air conditioners, on the other hand, showed no evidence, in a controlled trial, of protecting patients against bacterial contamination. In spite of a reduction of about $50 \%$ in the number of airborne staphylococci in air-conditioned rooms, patients in such rooms showed as much infection with Ps. aeruginosa, and even with Staph. aureus, as those in window-ventilated rooms. The dressings of these patients were always changed in an air-conditioned dressing-station which was previously shown to have a useful protective function (Lowbury, 1954).

Treatment with compresses and with isolators is timeconsuming, uncomfortable for the patients, impracticable for more than a small number of patients at a time, and unneces- 
sary for those with burns of small extent that carry no risk of death from infection. Because of the potential value of these methods as life-saving measures in very severely burned patients, it is logical to reserve them for the treatment of such patients, and possibly for others who are "infection-prone" (Jones and Lowbury, 1965). If full use is made of available methods which have been shown to have prophylactic value, it should be possible to prevent the majority of invasive infections in such patients. This would involve the simultaneous use of some or all of the following barriers against infection-(1) barriers against contamination of burns : (a) silver nitrate compresses, and (b) treatment in an isolator; (2) barriers against invasion of tissues: (a) systemic chemotherapy, including the use of a new antibiotic against Ps. aeruginosa (Jones and Lowbury, 1966), and (b) the use of hyperimmune sera (Millican and Rust, 1960 ; Feller, 1966 ; Jones and Lowbury, 1965 ; Jones, Jackson, and Lowbury, 1966).

Prophylaxis against infection in patients with smaller burns, though less imperative, is desirable not only for the prevention of sepsis and graft failure in the patients so treated but also for the control of infection in the ward. Silver nitrate cream, possibly with the addition of chlorhexidine or of an antibiotic active against staphylococci and coliform bacilli (for example, gentamicin), might be a suitable choice for burns treated with dressings ; more work is needed to establish the optimum concentration of silver nitrate and the most suitable additional agents for use in creams. Powders and sprays have shown limited prophylactic value for burns treated by the exposure method (for example, Lowbury et al., 1962b) ; the most effective prophylaxis for exposed burns can probably be obtained from the use of isolators together with systemic prophylaxis by antibiotics.

The limited reduction in airborne bacteria achieved by the use of portable air-conditioning units was apparently too small to cause any reduction in infection of burns. A more effective ventilation system would possibly have had such an effect, but it seems likely that the chief promise for improvement in the aseptic control of infection lies in the development of isolators. It is important, however, that air-conditioned dressing-stations (or cubicles) should be available for the removal of dressings from patients who are not nursed in an isolator or treated with silver nitrate compresses.

\section{Summary}

Methods of preventing contamination of burns are described. Controlled trials showed the outstanding prophylactic value of $0.5 \%$ silver nitrate compresses applied to burns, and significant, though smaller, effects of a cream containing $0.5 \%$ silver nitrate. The greatest effect was against Ps. aeruginosa and Proteus spp.; a trial in patients with extensive burns showed Ps. aeruginosa in $70 \%$ of swabs from the control series (treated with penicillin cream), but in only $3.1 \%$ of swabs from the series treated with silver nitrate compresses. Several patients with extensive burns remained free from $P$ s. aeruginosa for two to three weeks. There was less prophylactic effect against Staph. aureus and none against certain coliform bacilli. Treatment with silver nitrate applications was associated with lower mean temperature and respiration rates, and other clinical advantages. No toxic effects attributable to silver nitrate were detected, and the applications, though uncomfortable, were not painful.

Preliminary studies on a ventilated plastic isolator have given promising results. Patients in the isolator were protected against contamination with airborne organisms and by contact; there was evidence of less infection, including prolonged absence of Ps. aeruginosa in extensive burns. By contrast, the conversion of an open ward into one with cubicles and the subsequent introduction of portable air-conditioners into half of them did not lead to any fall in the proportion of infected burns.

The simultaneous use of antiseptic and aseptic barriers against contamination (silver nitrate compresses and isolators) and of chemotherapeutic or serological barriers against invasion is suggested for the protection of severely burned or " highrisk" patients.

We wish to thank Sister Nicholls, S.R.N., and the nursing staff of the Burns Unit ; Mr. H. A. Lilly, F.I.M.L.T., Mr. M. Wilkins, A.I.M.L.T., and Mr. R. J. Babb, A.I.M.L.T., of the M.R.C. Bacteriology Laboratory, and our clinical colleagues for their co-operation; Dr. Harvey Bernard, of St. Louis, Missouri, and Professor R. A. Shooter for strains of Ps. aeruginosa; J. A. Radley Laboratories Ltd. for analyses of silver; Vickers Research Laboratories for plastic isolators ; and Miss C. Sivell for help with the analyses.

\section{REFERENCES}

Barber, M., and Kuper, S. W. A. (1951). 7. path. Bact., 63, 65. Bettman, A. G. (1936). Surg. Gynec. Obstet., 62, 458.

Bourdillon, R. B., and Colebrook, L. (1946). Lancet, 1, 561, 601.

Brown, V. I., and Lowbury, E. J. L. (1965). 7. clin. Path., 18, 752.

Bull, J. P., and Fisher, A. J. (1954). Ann. Surg., 139, 269.

Cason, J. S., and Lowbury, E. J. L. (1960). Lancet, 2, 501.

Colebrook, L. (1950). A New Approach to the Treatment of Burns and Scalds. London.

Cowan, S. T., and Steel, K. J. (1965). Manual for the Identification of Medical Bacteria. Cambridge.

Feller, I. (1966). Second International Congress on Research in Burns, edited by A. B. Wallace and A. W. Wilkinson, p. 56. Edinburgh.

Geitler, Rhoades, and Weiss (1927). Cited in Hill and Pillsbury (1939).

Haynes, B. W., and Hench, M. E. (1966). Second International Congress on Research in Burns, edited by A. B. Wallace and A. W. Wilkinson, p. 78. Edinburgh.

Hill, W. R., and Pillsbury, D. M. (1939). Argyria: The Pharmacology of Silver. Baltimore.

Jackson, D. M., Lowbury, E. J. L., and Topley, E. (1951). Lancet, 2. 137.

Jones, R. J., Jackson, D. M., and Lowbury, E. J. L. (1966). Brit. F. plast. Surg., 19, 43.

- and Lowbury, E. J. L. (1965). Lancet, 2, 623.

- (1966). Submitted for publication.

Kalt (1851). Cited by H. N. Harkins, The Treatment of Burns, 1942. Springfield.

Levenson, S. M., Trexler, P. C., LaConte, M., and Pulaski, B. J. (1964). Amer. F. Surg., 107, 710.

Lindberg, R. B., Moncrief, J. A., Switzer, W. E., Order, S. E., and Mills, W. (1965). F. Trauma, 5, 601 .

Lowbury, E. J. L. (1954). Lancet, 1, 292.

- (1960). Brit. med. F., 1, 994.

- Babb, R. J., Brown, V. I., and Collins, B. J. (1964). F. Hys. (Lond.), 62, 221.

- and Fox, J. E. (1954). Ibid., 52, 403.

- Miller, R. W. S., Cason, J. S., and Jackson, D. M. (1962b). Lancet, 2, 958.

- Lilly, H. A., and Wilkins, M. D. (1962a). F. clix. Path., 15, 339.

Millican, R. C., and Rust, J. D. (1960). F. infect. Dis., 107, 389.

Moyer, C. A., Brentano, L., Gravens, D. L., Margraf, H. W., and Monafo, W. W. (1965). Arch. Surg., 90, 812. 